\title{
Somatic cell count in milk of Finnsheep ewes and relation with production results
}

\author{
Z. J. TYSZKA and M. KRAMARZ \\ Warsaw Agricultural University, Institute of Biological Bases of Animal Breeding, \\ ul. Przejazd 4, 05-840 Brwinów, Poland
}

\begin{abstract}
Finnsheep ewes were tested for milk quality and productivity (lambs and wool) on an experimental farm in two years. Milk samples were taken in first, second and third month of lactation to qualify - somatic cell count (SCC) - and percentage of fat (F \%), protein (P \%) and lactose (L \%). For the calculation, logarithmic SCC (LSCC) was used. Data concerning rearing of lambs and wool production were calculated with each sample during lactation.

Differences in all tested traits were found. Season 1981 proved to be better than 1983 . For all observations LSCC was 2.16 and milk composition as follows: F \% 5.38, P \% 5.42 and $\mathrm{L} \% 4.74$. From average ewe there were 2.42 born lambs $(6.18 \mathrm{~kg}), 1.14$ weaned lambs $(20.09 \mathrm{~kg})$ and $1.24 \mathrm{~kg}$ of wool for six months. Correlation coefficients between LSCC and traits tested were: $\mathrm{F} \%-0.07, \mathrm{P} \%-0.02, \mathrm{~L} \%-0.53$, wool yield -0.09 , number of weaned lambs -0.01 , weight of weaned lambs 0.00 . For all above coefficients the error was 0.05 . Those tests concerned limited number of animals and will be continued.
\end{abstract}

Index words: Finnsheep, somatic cell count, milk composition, fat, protein, lactose, lamb rearing, wool production

\section{Material and methods}

Finnsheep ewes have been crossed in many countries with local breeds in order to reach higher fertility. After 1975 a flock of sheep from Finland was moved to Experimental Sheep Farm Koluda Wielka in Poland. For this flock wholesomeness of udders and milk composition were tested in 1981 and 1983. Results of the tests were later compared with productive traits i.e. wool yield, reproductive performance and rearing of lambs.
35 ewes in 1981 and 22 ewes in 1983 were observed. Milk samples were taken three times, during first, second and third month of lactation and always three times a day at $6.00,12.00$ and $18.00 \mathrm{hrs}$.

Somatic cell count (SCC) was determined by Fossomatic celloscope with the accuracy of 1.000 per $1 \mathrm{ml}$. Fat $(\mathrm{F} \%)$, protein $(\mathrm{P} \%)$ and lactose $(\mathrm{L} \%)$ percentages were calculated with Milkoscan apparatus.

SCC as an indicator of udder health was 
used for statistical calculations, where real values were measured in scores as below:

$\begin{array}{lrr}\text { up to } & 300.000 & 1 \\ 300.000- & 500.000 & 2 \\ 500.000-1.000 .000 & 3 \\ \text { over } \quad 1.000 .000 & 4\end{array}$

or transferred into logharithmic values (LSCC).

Figures concerning wool yield (from the first shearing after lactation), number and body weight of born and weaned (100 days old) lambs, for the six months period were taken from the breeding records.

The level of measured traits was calculated separately for both years, as well as jointly for all observations, and so were calculated changes in milk composition and SCC (both in scores and LSCC). Correlation coefficients between the above ways of expressing SCC and tested traits of reproductive performance rearing and wool yield were calculated. Those coefficients were calculated for both tested years separately and jointly for all observations.

\section{Results}

The results are shown in tables 1,2 and 3 . Table 1 shows that the level of observed traits was different for both years. In 1983 more lambs were born (by $0.41 \%$ ) but they were lighter (1,96 kg vs. $2,61 \mathrm{~kg}$ in 1981) and many more lambs died than in 1981, during rearing period. Body weights of weaned lambs were similar for both years (1981: $17.68 \mathrm{~kg}$; 1983: $17.58 \mathrm{~kg}$ ) but the weight of the weaned litter was higher in 1981 by $2.75 \mathrm{~kg}$.

Also in 1981 wool yield was almost twice as high, and the level of nutritive components in milk ( $\mathrm{F} \%, \mathrm{~L} \%, \mathrm{P} \%)$ higher.

Health of udders was also better in 1981 . SCC expressed in LSCC and scores was lower in 1981.

Geometrical means for SCC were 138.000 (1981) and 224.000 (1983). We have to state that 1981 was better for the tested flock, with the exception that litter size at birth was higher in 1983. For all observed traits variability was high.

Table 2 shows changes in milk composition.

Table 1. Values of the tested traits.

\begin{tabular}{|c|c|c|c|c|c|c|}
\hline \multirow[t]{2}{*}{ Trait } & \multicolumn{2}{|c|}{1981} & \multicolumn{2}{|c|}{1983} & \multicolumn{2}{|c|}{$1981+1983$} \\
\hline & $\bar{x}$ & $\delta$ & $\bar{x}$ & $\delta$ & $\overline{\mathbf{x}}$ & $\delta$ \\
\hline Udder health (scores) & 1,46 & 0,96 & 1,83 & 1,26 & 1,51 & 0,98 \\
\hline LSCC & 2,14 & 0,66 & 2,35 & 0,83 & 2,16 & 0,69 \\
\hline No. of lambs born & 2,39 & 0,83 & 2,80 & 0,68 & 2,42 & 0,82 \\
\hline No. of lambs weaned & 1,15 & 0,69 & 1,00 & 0,84 & 1,14 & 0,70 \\
\hline Weight of lambs born & 6,24 & 1,94 & 5,49 & 1,23 & 6,18 & 1,90 \\
\hline Weight of lambs weaned & 20,33 & 14,33 & 17,58 & 16,74 & 20,09 & 14,56 \\
\hline Wool yield (6 month) & 1,30 & 0,36 & 0,68 & 0,27 & 1,24 & 0,39 \\
\hline Fat $\%$ & 5,60 & 2,28 & 3,76 & 2,03 & 5,38 & 2,34 \\
\hline Protein $\%$ & 5,46 & 1,43 & 5,13 & 1,22 & 5,42 & 1,42 \\
\hline Lactose $\%$ & 4,84 & 1,28 & 4,03 & 1,75 & 4,73 & 1,37 \\
\hline
\end{tabular}

Tabie 2. Changes in milk composition during lactation (for all observations).

\begin{tabular}{|c|c|c|c|c|c|c|}
\hline \multirow[t]{2}{*}{ Trait } & \multicolumn{2}{|c|}{ Period 1} & \multicolumn{2}{|c|}{ Period 2} & \multicolumn{2}{|c|}{ Period 3} \\
\hline & $\overline{\mathbf{x}}$ & $\delta$ & $\overline{\mathrm{x}}$ & $\delta$ & $\overline{\mathbf{x}}$ & $\delta$ \\
\hline Udder health (scores) & 1.36 & 0.75 & 1.58 & 1.00 & 1.59 & 1.05 \\
\hline LSCC & 2.16 & 0.55 & 2.23 & 0.65 & 2.11 & 0.75 \\
\hline Fat $\%$ & 5.92 & 2.10 & 5.75 & 2.60 & 4.38 & 1.75 \\
\hline Protein \% & 5.08 & 1.00 & 5.70 & 1.80 & 5.53 & 1.15 \\
\hline Lactose $\%$ & 5.80 & 1.00 & 4.20 & 1.05 & 4.06 & 1.15 \\
\hline
\end{tabular}


Table 3. Coefficients of correlation between somatic cell count in milk (in scores and logarithms) and productive traits.

\begin{tabular}{|c|c|c|c|c|c|c|c|c|c|}
\hline & \multicolumn{3}{|c|}{$\%$ in milk } & \multirow{2}{*}{$\begin{array}{c}\text { Wool } \\
\text { yield } \\
(6 \mathrm{mth})\end{array}$} & \multicolumn{2}{|c|}{ No. of lambs } & \multicolumn{2}{|c|}{ Weight of lambs } & \multirow{2}{*}{ Errors } \\
\hline & fat & protein & lactose & & born & weaned & born & weaned & \\
\hline \multicolumn{10}{|l|}{1981} \\
\hline Scores & $-0,16$ & $-0,01$ & $-0,58$ & $-0,04$ & $-0,11$ & 0,07 & $-0,04$ & 0,07 & $0,04-0,05$ \\
\hline LSCC & $-0,05$ & $-0,01$ & $-0,48$ & $-0,08$ & $-0,16$ & 0,03 & $-0,09$ & 0,02 & \\
\hline \multicolumn{10}{|l|}{1983} \\
\hline Scores & $-0,01$ & $-0,04$ & $-0,72$ & 0,25 & 0,32 & $-0,01$ & 0,24 & $-0,05$ & $0,12-0,15$ \\
\hline LSCC & $-0,03$ & $-0,08$ & $-0,75$ & 0,26 & 0,30 & 0,02 & 0,23 & 0,01 & \\
\hline \multicolumn{10}{|l|}{$1981+1983$} \\
\hline Scores & $-0,17$ & $-0,01$ & $-0,62$ & $-0,04$ & $-0,04$ & 0,03 & $-0,03$ & 0,04 & $0,04-0,05$ \\
\hline LSCC & $-0,07$ & $-0,02$ & $-0,53$ & $-0,09$ & $-0,10$ & $-0,01$ & $-0,08$ & 0,00 & \\
\hline
\end{tabular}

It was observed that during lactation $\mathrm{L} \%$ and $\mathrm{F} \%$ in milk were decreasing.

$\mathrm{P} \%$ was highest in the second month of lactation and later was getting lower. For SCC growing tendency was observed. During lactation, LSCC first grows and later decreases. Also table 2 shows high variability.

Table 3 contains correlation coefficients between SCC (scores and LSCC) and productive traits tested. The results confirm the difference between both years.

We may say that correlation between SCC and $\mathrm{L} \%$ is high and negative. Other coefficients are low and negative thus showing that with the increase of SCC in Finnsheep milk, the level of productive traits decreases. Only the body weight of weaned lambs does not depend on SCC level in milk. The results obtained are considered preliminary, since the observations are being continued and further results will be published.

The conclusions are as follows.

1. Differences were found in the level of tested traits for the two years. For the given flock, 1981 was better than 1983.

2. With increasing SCC in milk, the levels of $\mathrm{L} \%, \mathrm{~F} \%$ and $\mathrm{P} \%$ in milk decrease. Also wool yield, number and weight of born lambs decrease.

3. Correlation coefficients are low. 